\title{
COGNITIVE-INDIVIDUAL, LINGUISTIC AND DEMOGRAPHIC VARIABLES, AND SYNTACTIC ABILITIES IN FOREIGN LANGUAGE
}

\author{
Eva STRANOVSKÁ ${ }^{1}$, Daša MUNKOVÁ ${ }^{2}$, Michal MUNK ${ }^{3}$, Ivan SARMÁNY SCHULLER ${ }^{4}$ \\ 'Department of German Studies, Faculty of Arts CPU \\ Štefánikova 67, 94974 Nitra, Slovak Republic \\ E-mail: estranovska@ukf.sk \\ ${ }^{2}$ Department of Translation Studies, Faculty of Arts CPU \\ Štefánikova 67, Nitra, Slovak Republic \\ E-mail: dmunkova@ukf.sk \\ ${ }^{3}$ Department of Informatics, Faculty of Natural Sciences CPU \\ Tr. Andreja Hlinku 1, Nitra, Slovak Republic \\ E-mail: mmunk@ukf.sk \\ ${ }^{4}$ Institute of Experimental Psychology, Slovak Academy of Sciences \\ Dúbravská cesta 9, 84104 Bratislava, Slovak Republic \\ E-mail: expssarm@savba.sk
}

\begin{abstract}
The research was aimed at finding the measure of influence of cognitive-individual variables (Need for Structure, Ability to Achieve Cognitive Structure, Self-Esteem, Cognitive Style 'Category Width'), linguistic variables (Verbal Intelligence, Morphology Score), and demographic variables (Study-year, Grade, Living abroad) on syntactic abilities of students studying English language and culture at the Constantine the Philosopher University in Nitra. Subsequently, we investigated the relation between syntactic ability and chosen variables. We used the following research methods: PNS Scale (Thompson et al., 1992), AACS (Bar-Tal, 1994), RSES (Rosenberg, 1965), C-W (Pettigrew, 1958), I-S-T (Amthauer, 1953, in Halama, Tomková, 2005), and Syntactic Abilities Test (Užáková et al., 2010). Findings showed a negative correlation between syntactic abilities and Morphology Score, between Study-year, Morphology Score and Grade. A positive correlation was observed between syntactic ability and Verbal Intelligence, and a negative correlation between Verbal Intelligence and Need for Structure. The observed variables explain 34\% variability of syntactic ability in foreign language.
\end{abstract}

Key words: cognitive-individual variables, demographic variables, linguistic variables, syntactic

\section{INTRODUCTION}

Syntax is for cognitive psychologists (Gardner, 1999; Eysenck, Keane, 2008; Sternberg, 2009 and others) a remarkable source for research in the area of foreign language acquisition. Foreign language acquisition is understood as a broader concept, encompassing learning, in the socio-psychological sense, unintentional and intentional processes. These concepts interrelate, depending on the overlap between spontaneous and controlled processes (implicit and explicit theories of learning which stimulate different learning mechanisms (more Stranovská, 2011).

One of the purposes of examining syntax in cognitive psychology is to determine the extent to which individuals are able to understand syntactic structures and process them. Gardner (1999) and Sternberg (2009) 
emphasize the importance of syntax because it is manifested by the feel for mother tongue and foreign language, and by verbal creativity. According to Vágnerová (2001), syntactic reasoning requires activation of large brain areas connected with the function of speech centers. It includes syntactic ability to analyze speech utterances in terms of composition of words into higher units and to distinguish factors of word order. A part of the acquisition of this ability is also distinguishing utterances according to the speaker's communication intent, the ability to create an utterance in their own speech and adequately respond to the same kind of utterance.

The role of an individual is to acquire the means of concept combinations, including the order in which they are arranged and produced. It is a deeper insight into language structures whose production has not only a linguistic but also a cognitive-individual dimension (every person produces them in an individual way). Demographic dimension also needs to be taken into consideration because demographic variables may have a different effect on the individual's syntactic ability. For this reason, we consider studying syntactic abilities in the context of cognitive-individual, linguistic and demographic variables in the process of foreign language acquisition as essential.

The aim of this study is to determine the extent to which cognitive-individual, linguistic and demographic variables affect the individual's syntactic abilities in a foreign, in our case the English language; and to determine their mutual relations. We suppose that syntactic abilities are related not only to linguistic but also to cognitive-individual and demographic variables. We studied the following variables: Ability to Achieve Cogni- tive Structures, Personal Need for Structure, Cognitive Style Category Width, Self-esteem, Verbal Intelligence, Morphology Score, Study-year, Grade and Living Abroad which are considered to be the predictors of communication skills and success in foreign language learning (Brown, 2000, 2008; Ehrman, Oxford, 1990, 1995; Dörney, Skehan, 2003; Dalgas-Pelish, 2006; Liu, 2012 and others). Interactions of these variables have not yet been explored deeper or analyzed in relation to syntactic abilities.

For this reason, research has been carried out, in which 114 students of English language and culture took part.

This study is further divided into several sections: section two characterizes cognitive-individual, linguistic and demographic variables, and refers to similar studies about these variables. Section three describes methods used within the research. A summary of the research outcomes and the analysis of the variables influence on syntactic abilities can be found in section four. Discussion and conclusion are presented in the final section five.

\section{COGNITIVE-INDIVIDUAL, LINGUISTIC AND DEMOGRAPHIC VARIABLES}

For the last decade, many specialists in the area of psycholinguistic, psychological and linguistic sciences (Cooper, 2002; Skehan, 1998; Dörney, Skehan, 2003; Brown, 2000, 2008; Liu, 2012 and others) have tried to understand individual differences or factors affecting various levels of foreign language learning (age, time, confidence, motivation, language skills, learning strategies, learning and cognitive styles, etc.).

Personal Need for Structure (PNS) or uncertainty in cognitive decision-making is a 
part of the process of foreign language learning (processing syntactic, semantic and morphological forms, perception of cultural differences in sentences, etc.). Uncertainty in cognitive decision-making, according to Neuberg et al. (1997); Neuberg and Newsom (1993), can be manifested by avoiding uncertain situations (selection of simple sentences, word combinations and simple meanings). A person with high PNS score prefers simplicity, accuracy and structure in most situations. In uncertain situations (speech) he/she feels uncomfortable and insecure (Thompson et al., 1992; see also Neuberg, Judice, West, 1997; Neuberg, Newsom, 1993). Bar-Tal (1994), Bar-Tal, Spitzer (1999) and BarTal, Guinote (2002) showed in their research that there are differences in how we make decisions in situations of uncertainty. Although uncertainty cannot be excluded from the process of foreign language learning, this influence can be minimized (John et al., 2000).

The variable Ability to Achieve Cognitive Structure $(A A C S)$ is the extent to which an individual is able to avoid pieces of information that do not correspond to his/her existing cognitive structure (Bar-Tal, 1994; BarTal, Spitzer, 1999; Bar-Tal, Guinote, 2002). We describe the characteristics of the ability to achieve cognitive structure as tolerance for ambiguity in a foreign language. Ambiguous situation is in our case the formation and differentiation of sentence structures in a foreign language. Tolerance for ambiguity in a foreign language is one of the learning styles; it is the ability of an individual to tolerate ambiguity without frustration. Chapelle, Roberts (1986), Ehrman, Oxford $(1990,1995)$ and Brown (2000) consider tolerance for ambiguity as an important indicator in foreign language learning. Brown
(2000), however, points out that a high rate of tolerance for ambiguity may not function as an indicator but as an inhibitor. This is the case when an individual is excessively tolerant to ambiguity, which prevents him/ her from creating meaningful explanations, rules and a system in a foreign language.

Horwitz at al. (1986) and Brown (2008) have carried out several research studies that showed the impact of self-esteem (RSES) and anxiety in the process of foreign language learning. Individuals who show high selfesteem are expected to have a low level of anxiety, which can help them to achieve greater success in language acquisition. Coopersmith (1981) defines self-esteem as "the evaluation a person makes and customarily maintains with regard to him- or herself". It indicates to what extent the person believes in him/herself. Individuals with high self-esteem are more creative, very often and effectively express their views, possess a higher quality of learning strategies (Watkins, $2000)$, they very likely achieve success in education (Dalgas-Pelish, 2006; Stringer, Heath, 2008), and are less anxious (Situ, Li, 2007).

The impact of the variable Cognitive Style 'Category Width' $(C-W)$ on the process of foreign language acquisition is manifested mainly in strategies of sentence construction processing (broad versus narrow categorizers) as well as in real estimations of individuals in ambiguous situations.

Sarmány-Schuller (1997) connects in his research of the 'category width' cognitive style personality with cognitive processes. This connection is examined by Stranovská et al. (2011) in the production of speech acts in foreign language (selection of politeness elements in producing requests by narrow and broad categorizers). 
Verbal Intelligence (VIQ) in terms of foreign language learning is an issue discussed in connection with clarifying the structure of talents. Skehan (1998) identifies phonemic coding ability, linguistic analytical ability and memory ability. Carroll (1997), as opposed to Skehan's structure of talents, adds grammatical sensitivity. Gardner (1999) highlights particularly syntax and phonology. He claims that syntax and phonology are close to the center of language intelligence, whereas semantics and pragmatics make use of inputs from other intelligences (for example from logical-mathematical, personal and social intelligence). Dolník (2007) considers language intelligence a general term covering linguistic-operational intelligence and communication intelligence. Linguistic-operational intelligence is reflected in the user's operations with language elements. Riemer (1997) considers verbal intelligence as an endogenous factor that influences the process of foreign language acquisition in terms of predisposition for language abilities.

Morphology or correct use of rules belongs to the most frequently studied variables in foreign language acquisition. There are two groups with different opinions in cognitive linguistics about child's development in relation to grammatical rules. The first group argues that rules are the result of learning (Repka, Gavora, 1987 and others). The second group says that a part of the grammatical rules is innate (Chomsky, 1972; Pinker, 2009). Research in the field of morphology is often connected with the age factor or cognitive development. Cameron (2001) showed in his research that as the child gets older its grammatical abilities improve. He says that cognitive development can be seen as the main factor positively influencing the rate of foreign language learning. Piaget (1970) also believes that the child's thinking and reasoning ability evolves during the process of development. For this reason, he does not recommend to teach children grammatical rules until they are eleven years old.

Demographic variables such as years of foreign language study, living abroad, grade, etc. further specify many positive or negative effects and causes of success or failure in foreign language acquisition. The variable length of foreign language learning is the most often discussed variable among experts in psycholinguistics (Riemer, 1997 and others) who examine the hypothesis of critical period (the ability to acquire foreign language is dependent on age). Lennenberg (1967) says that the turning point in the natural acquisition of a foreign language is the period between the third and the fifth year of life. A wide range of research studies have been conducted to prove or disprove this theory. Most of these studies, however, focused on phonetics (more Stranovská, 2011).

\section{METHODS}

\section{Research Sample}

The research was carried out in academic years 2009/2010 and 2010/2011 at the Department of Language Pedagogy and Intercultural Studies, Faculty of Education, Constantine the Philosopher University in Nitra (Slovak Republic).

114 students took part in the research (31 men, 83 women), students of first, second and third year of English Language and Culture studies (full-time study). The average age of the students was 20. These students have been learning English for 9-12 years on average, since the 3rd - 6th grade of basic school. $2 \%$ of these students have started 
to learn English in an early age of their childhood.

\section{Hypotheses}

Assuming that syntactic ability is related not only to linguistic but also to cognitiveindividual and demographic variables, we set the following hypotheses:

- There is a positive relation between syntactic ability and linguistic variables (Morphology Score and Verbal Intelligence).

- There is a positive relation between syntactic ability and cognitive-individual variables (Ability to Achieve Cognitive Structure, 'Category Width' Cognitive Style and Self-esteem) and a negative relation between syntactic ability and Personal Need for Structure.

- There is a positive relation between syntactic ability and demographic variables (Grade, Study-year and Living Abroad).

- Cognitive-individual, linguistic and demographic variables have a statistically significant effect on syntactic ability (using forward stepwise regression).

- There is a positive relation between linguistic variables and cognitive-individual variables (Ability to Achieve Cognitive Structure, Cognitive Style 'Category Width' and Self-esteem) and a negative relation between syntactic ability and Personal Need for Structure.

\section{Methods}

PNS Scale-Personal Need for Structure, which arises from the assumption that the ability to reduce uncertainty of a situation is connected with managing new situations. The authors of this theory are Thomson, Naccarato and Parker (1992).
The scale contains 12 items. The PNS construct is based on a two-factor conception of personal need for structure (SarmánySchuller, 1999): 1) desire for structure (subfactor $F 1$ ), 2) reaction to a missing structure (sub-factor $F 2$ ).

AACS Scale (Bar-Tal, 1994) consists of 24 items, which determine a) self-reported ability to achieve confidence in correct decisionmaking; b) ability to acquire clarity of solutions and c) ability to structure life. AACS can be considered a measure of the extent to which individuals are able to apply strategies in information processing that are in compliance with their personal need for cognitive structure (Bar-Tal, Spitzer, 1999). With the help of AACS Scale we studied how students react in an uncertain situation, to what extent they evaluate themselves through tolerance to frustration, and if they are able to gain a sense of certainty of a situation or confidence. The higher ability to achieve cognitive structure students have, the higher reaction flexibility in an uncertain situation and higher frustration tolerance in uncertain situations they show. In our case, the uncertain situation means expressing themselves in a foreign language, a kind of test in which students had to produce sentences according to models, make selections and corrections of incorrect sentence constructions, and determine sentence structures.

Estimation Scale C-W (Category Width): $\mathrm{C}-\mathrm{W}$ Scale measures the Cognitive Style 'Category Width' and real estimation. The author is Pettigrew, Slovak translation was done by Sarmány-Schuller and Jurčová (1993) who pointed to the adaptation process of this method in Slovak environment. It contains 20 statements that suggest certain statements in the form of an average value and the respondent has to guess which 
of the four fixed numerical alternatives corresponds with the highest and lowest number of occurrences of a given phenomenon. The tasks are not aimed at determining knowledge; they should reveal how students can estimate the answer to a given task. Questionnaire items contain estimation of speed, size, time and various other data.

RSES: To monitor the level of self-esteem scale we used the Rosenberg Self-Esteem Scale RSES. The Slovak version of RSES was elaborated, adapted and verified by Ficková (2000). The scale contains ten items, six of which are formulated positively and four negatively. Individual items are rated by respondents on a four-point scale from strongly disagree to strongly agree. The scales are designed in a way that a high score means a high level of self-esteem. In the Czech Republic it was analyzed by Blatný and Osecká (1994), in Slovakia by Ficková (2000) and Gurňáková (2000).

Intelligence Structure Test I-S-T, Verbal Intelligence Sub-tests, whose author is Amthauer, has been well-known since 1953 and diagnoses not only the overall level of intelligence, but provides information about its structure as well (in Halama, Tomková, 2005). General intelligence test for adults measures the general level of intelligence and its structure. In Slovakia, the manual of Intelligence Structure Test was published in 1973 and elaborated by Hrabal (1973, in Halama, Tomková, 2005). In 1993 the revised edition of Intelligence Structure Test was published in Psycholinguistics with the title IST 70 and was adapted by Vonkomer (in Halama, Tomková, 2005). This version includes 9 sub-tests (Sentence Completion, Word Choice, Verbal Analogies, Verbal Similarities, Numerical Calculations, Number Series, Figure Selection, Cubes, and Memory).
We focused on three sub-tests that measure verbal intelligence:

Sub-test 1 - Sentence Completion (SC), Sub-test 2 - Word Choice (WC), Sub-test 3 - Analogy (AN)

Each sub-test consists of twenty tasks. Respondents choose the correct answer out of the options ranging from $a$ to $e$.

Test of Syntactic Abilities: The test measures the ability to create syntactic structures, which means the ability to create sentence compositions in the English language, the perception of syntactic sentence structure, language intuition, creativity as well as flexibility. The author is Užáková et al. (2010). The test was developed for the means of determining syntactic abilities of students after completing the Syntax Course within the curriculum. Syntax is one of the compulsory courses of the English Language studies. It includes 80 items divided into four areas:

1)Analyzing sentence parts and compound sentences

2) Creating sentences and compound sentences on the basis of a given structure (giving sentence examples)

3) Compound sentences composition (composing one compound sentence out of simple sentences)

4) Analyzing meaning of syntactic structure (correct understanding of the meaning of a sentence, correcting sentences with incorrect word-order or improper expression).

Score in Morphology: We used the following scale: 1-A, 2-B, 3-C, 4-D and 5-F.

\section{RESULTS}

Table 1a illustrates a descriptive statistics of individual variables: Study-year, Cognitive Style 'Category Width' $(a+b)$, Real Es- 
timation (a-b), Ability to Achieve Cognitive Structure (AACS), Verbal Intelligence (VIQ), Personal Need for Structure (PNS), the Rosenberg Self-Esteem Scale (RSES), Syntactic Ability (a score in Syntax test) and Morphology (a Score in Morphology).

Based on the results of descriptive statistics, students involved in research show a higher ability to achieve cognitive structure, high self-esteem, narrow categorization, high measure of real estimation, average verbal intelligence, average syntactic ability and an average score in morphology (1-A, 2-B, 3-C, 4-D and 5-F), personal need for structure in a moderate range, and an average of studyyears of foreign language - ten years, that means he/she started to study English in the 3-6 grade in basic school. In terms of the variable Living Abroad, 53 students spent more than one month abroad and 61 students have never spent a longer period of time in an English speaking country (Table 1b).

Table 2 depicts statistically significant correlations of syntactic ability and the individual variables as well as between them mutually $(p<0.05)$. The coefficients of correlation matrix (Table 2) show a statistically significant relation between syntactic ability (score in Syntax test) and linguistic variables, specifically, a positive correlation of syntactic ability and verbal intelligence $(\mathrm{r}=0.320, \mathrm{p}<0.01)$ and a negative correlation of syntactic ability and morphology score $(\mathrm{r}=-0.463, \mathrm{p}<0.01)$. Furthermore, a statistically significant relation of syntactic ability was identified with the demographical variable study-year $(\mathrm{p}<0.05)$. The coefficient of correlation $(r=-0.193)$ depicts a negative

Table 1a. Descriptive statistics of the cognitive-individual, demographical and linguistic variables

\begin{tabular}{|l|c|c|r|r|r|r|r|r|r|r|r|}
\hline & $\mathrm{N}$ & Mean & Median & Min & Max & $\begin{array}{c}\text { Lower } \\
\text { Quartile }\end{array}$ & $\begin{array}{c}\text { Upper } \\
\text { Quartile }\end{array}$ & Range & $\begin{array}{c}\text { Quartile } \\
\text { Range }\end{array}$ & $\begin{array}{c}\text { Std. } \\
\text { Dev. }\end{array}$ & $\begin{array}{c}\text { Coef. } \\
\text { Var. }\end{array}$ \\
\hline Study-year & 114 & 10.48 & 11 & 2 & 16 & 9 & 12 & 14 & 3 & 2.67 & 25.52 \\
\hline AACS & 114 & 86.22 & 86.5 & 55 & 127 & 77 & 94 & 72 & 17 & 12.16 & 14.10 \\
\hline PNS & 114 & 45.10 & 45 & 23 & 63 & 41 & 50 & 40 & 9 & 7.91 & 17.54 \\
\hline $\mathrm{a}+\mathrm{b}$ & 114 & 53.05 & 54.5 & 0 & 101 & 43 & 64 & 101 & 21 & 16.42 & 30.95 \\
\hline $\mathrm{a}-\mathrm{b}$ & 114 & -3.12 & -3 & -26 & 22 & -8 & 3 & 48 & 11 & 7.97 & -255.12 \\
\hline RSES & 114 & 30.21 & 30 & 17 & 40 & 27 & 35 & 23 & 8 & 5.37 & 17.77 \\
\hline Syntax & 114 & 39.69 & 40 & 10 & 72 & 28 & 51 & 62 & 23 & 13.73 & 34.59 \\
\hline Morphology & 114 & 2.71 & 2.5 & 1 & 4 & 2 & 4 & 3 & 2 & 1.06 & 39.31 \\
\hline VIQ & 114 & 31.16 & 31 & 14 & 45 & 28 & 35 & 31 & 7 & 5.94 & 19.07 \\
\hline
\end{tabular}

Legend: $a+b$ - Cognitive Style Category Width, $a-b$ - Real Estimation, AACS - Ability to Achieve Cognitive Structure, VIQ - Verbal Intelligence, PNS - Personal Need for Structure, Syntax - Test of Syntactic Abilities, Morphology - Morphology Score, RSES - Self-esteem Scale, Living abroad - years spent in an English speaking country, Study-year - years of learning English language, Grade - years of studying English at university (age)

Table 1b. Descriptive statistics of linguistic variables

\begin{tabular}{|l|c|c|c|c|c|}
\hline & $\mathrm{N}$ & Count & Percent & Grade 1 & Grade 2 \\
\hline Living abroad & 114 & 61 & 53.51 & - & - \\
\hline Grade & 114 & - & - & 54 & 60 \\
\hline
\end{tabular}


Table 2. Correlation matrix of the examined variables

\begin{tabular}{|c|c|c|c|c|c|c|c|c|c|c|c|}
\hline $\mathrm{N}=114$ & Grade & iving & $\begin{array}{c}\text { Study- } \\
\text { year }\end{array}$ & AACS & PNS & $+\mathrm{b}$ & $a-b$ & SES & yntax & $\begin{array}{c}\text { Morpho- } \\
\text { logy }\end{array}$ & VIQ \\
\hline \multirow{2}{*}{ Grade } & \multirow{2}{*}{1.000} & 1991 & .1604 & .1872 & & & O & & & -.1857 & - \\
\hline & & $=.034$ & $=.088$ & $=.046$ & 270 & & & $=.081$ & & 048 & \\
\hline \multirow{2}{*}{$\begin{array}{l}\text { Living } \\
\text { abroad }\end{array}$} & & \multirow{2}{*}{1.000} & 0698 & -.0343 & .0891 & -.0148 & -.1430 & .0455 & 02 & -.1648 & .0375 \\
\hline & $=.034$ & & $=.460$ & & $=.346$ & & & $=.630$ & & $\mathrm{p}=.080$ & $=.692$ \\
\hline \multirow{2}{*}{$\begin{array}{l}\text { Study- } \\
\text { year }\end{array}$} & 504 & -.0698 & \multirow{2}{*}{1.000} & 095 & .0317 & .0216 & -.1243 & .1050 & & -.0508 & .0185 \\
\hline & 088 & $=.460$ & & & $=.738$ & $\mathrm{p}=.820$ & $\mathrm{p}=.188$ & $\mathrm{p}=.266$ & & $\mathrm{p}=.591$ & $=.845$ \\
\hline \multirow{2}{*}{ AACS } & & -.0343 & -.0095 & \multirow{2}{*}{1.000} & & & .0692 & .5557 & & .0054 & -.0970 \\
\hline & $\mathrm{p}=.046$ & $=.717$ & $p=.920$ & & $=.024$ & $=.066$ & $=.465$ & $\mathrm{p}=.000$ & 70 & $\mathrm{p}=.955$ & $\mathrm{p}=.305$ \\
\hline \multirow{2}{*}{ PNS } & & & & & \multirow{2}{*}{.000} & & & & & & \\
\hline & 270 & $=.346$ & $=.738$ & $p=.024$ & & 8 & $=.679$ & $\mathrm{p}=.169$ & $=.900$ & $=.655$ & $\mathrm{p}=.052$ \\
\hline \multirow{2}{*}{$a+b$} & & 8 & .0216 & & & \multirow[b]{2}{*}{1.000} & 0426 & & & .0244 & \\
\hline & $\mathrm{p}=.875$ & $\mathrm{p}=.876$ & $\mathrm{p}=.820$ & $\mathrm{p}=.066$ & $\mathrm{p}=.618$ & & $=.653$ & $\mathrm{p}=.212$ & $\mathrm{p}=.817$ & $\mathrm{p}=.796$ & $\mathrm{p}=.372$ \\
\hline \multirow{2}{*}{$a-b$} & 585 & -.1430 & -.1243 & .0692 & -.0391 & -.0426 & \multirow{2}{*}{1.000} & .0894 & & .0800 & .1165 \\
\hline & $\mathrm{p}=.537$ & $\mathrm{p}=.129$ & $\mathrm{p}=.188$ & $\mathrm{p}=.465$ & $\mathrm{p}=.679$ & $\mathrm{p}=.653$ & & $=.344$ & $\mathrm{p}=.988$ & $\mathrm{p}=.398$ & $\mathrm{p}=.217$ \\
\hline \multirow{2}{*}{ RSES } & .1639 & .0455 & .1050 & .5557 & -.1297 & \begin{tabular}{|c|}
-.1177 \\
\end{tabular} & .0894 & \multirow{2}{*}{1.000} & -.1557 & -.0162 & -.0305 \\
\hline & $\mathrm{p}=.081$ & $\mathrm{p}=.630$ & $\mathrm{p}=.266$ & $\mathrm{p}=.000$ & $\mathrm{p}=.169$ & $\mathrm{p}=.212$ & $\mathrm{p}=.344$ & & 8 & $\mathrm{p}=.864$ & $\mathrm{p}=.748$ \\
\hline \multirow{2}{*}{ Syntax } & 0952 & -.0402 & -.1928 & -.1293 & -.0119 & .0219 & .0014 & -.1557 & \multirow{2}{*}{1.000} & -.4633 & .3201 \\
\hline & $\mathrm{p}=.314$ & $\mathrm{p}=.671$ & $\mathrm{p}=.040$ & $\mathrm{p}=.170$ & $\mathrm{p}=.900$ & $\mathrm{p}=.817$ & $\mathrm{p}=.988$ & $\mathrm{p}=.098$ & & $=.000$ & $\mathrm{p}=.001$ \\
\hline \multirow{2}{*}{$\begin{array}{l}\text { Morpho- } \\
\text { logy }\end{array}$} & -.1857 & -.1648 & -.0508 & .0054 & .0423 & .0244 & -.0800 & -.0162 & -.4633 & \multirow{2}{*}{1.000} & -.2893 \\
\hline & $\mathrm{p}=.048$ & $\mathrm{p}=.080$ & $p=.591$ & $\mathrm{p}=.955$ & $\mathrm{p}=.655$ & $\mathrm{p}=.796$ & $\mathrm{p}=.398$ & $\mathrm{p}=.864$ & $\mathrm{p}=.000$ & & \\
\hline \multirow{2}{*}{ VIQ } & .0871 & .0375 & .0185 & -.0970 & -.1825 & -.0843 & .1165 & -.0305 & .3201 &.- .2093 & \multirow{2}{*}{1.000} \\
\hline & $\mathrm{p}=.357$ & $\mathrm{p}=.692$ & $\mathrm{p}=.845$ & $\mathrm{p}=.305$ & $\mathrm{p}=.048$ & $\mathrm{p}=.372$ & $\mathrm{p}=.217$ & $\mathrm{p}=.748$ & $\mathrm{p}=.001$ & $\mathrm{p}=.002$ & \\
\hline
\end{tabular}

correlation of syntactic ability and studyyear. A statistically significant relation has not been proven between syntactic ability and the demographic variables living $\operatorname{abroad}(\mathrm{p}=0.400)$ and study-year $(\mathrm{p}=0.314)$. Also, a statistically insignificant relation has been proven between syntactic ability and the following cognitive-individual variables: personal need for structure $(\mathrm{p}=0.900)$, ability to achieve cognitive structure $(\mathrm{p}=0.170)$, self-esteem $(\mathrm{p}=0.098)$, and cognitive style 'category width' $(\mathrm{p}=0.817)$.

A statistically significant relation was found between the linguistic variables mutually $(\mathrm{p}<0.01)$, the linguistic variable morphology score and the demographic variable study-year $(\mathrm{p}<0.05)$, and between the linguistic variable verbal intelligence and the cognitive-individual variable personal need for structure $(\mathrm{p}<0.05)$. A negative correlation has been identified between morphology score and verbal intelligence $(\mathrm{r}=$ $-0.289)$, morphology score and grade $(\mathrm{r}=$ -0.186), and verbal intelligence and personal need for structure $(\mathrm{r}=-0.183)$.

A statistically significant relation has been proven between cognitive-individual variables mutually $(\mathrm{p}<0.05)$, and between the cognitive-individual variable ability to achieve cognitive structure and the demographic variable grade $(\mathrm{p}<0.05)$. The variable ability to achieve cognitive structure correlates with personal need for structure negatively $(\mathrm{r}=-0.216, \mathrm{p}<0.05)$ and with the variable self-esteem positively $(\mathrm{r}=0.556, \mathrm{p}<0.01)$. Similarly, the variable ability to achieve cognitive structure correlates positively with grade $(\mathrm{r}=0.182, \mathrm{p}<0.05)$. 
A statistically significant positive correlation has been shown between the demographic variables grade and living abroad $(\mathrm{r}=0.199, \mathrm{p}<0.05)$.

\section{Analysis of the Impact of the Observed Variables on Syntactic Abilities}

The explanation rate of variability of the syntactic ability or the impact rate of the individual variables observed (VIQ, AACS, PNS, RSES, $a-b, a+b$, Morphology, Living abroad, Study-year) on syntactic ability (Syntax) is stated by a forward stepwise regression analysis, which enables individual adding of independent variables into the model in every step of regression until the moment when the best regression model is achieved.

We did not mean to achieve the best model but rather to assess the role of the individual examined independent variables in the explanation variability of the dependent variable Syntax.
As the table of stepwise summary (Table 3 ) shows, after entering one variable - Morphology, the determination index (R-square) increased by 0.215 . In the second step, two variables are in the regression equation, the variable Morphology and Study-year. The determination index (R-square) went up by 0.047 , i.e., this model explains $26 \%$ variability of the variable syntactic ability (Syntax). In the third step the variable VIQ was entered and the determination index (R-square) went up by 0.038 , i.e., this model explains $29 \%$ variability of the variable syntactic ability (Syntax). In the fourth step the variable $R S E S$ was entered, the determination index (R-square) went up by 0.018 , i.e., this model explains $31 \%$ variability of the variable syntactic ability (Syntax). In the fifth step, the variable Living Abroad was entered, the determination index (R-square) went up by 0.016 , i.e., this model explains 33\% variability of the variable syntactic ability (Syntax). In the sixth step, the variable $a-b$ was entered and the deter-

Table 3. Overview of stepwise regression - modeling of the dependent variable Syntax

\begin{tabular}{|l|c|c|c|c|c|c|c|}
\hline & $\begin{array}{c}\text { Step } \\
\text { +in/-out }\end{array}$ & $\begin{array}{c}\text { Multiple } \\
\mathrm{R}\end{array}$ & $\begin{array}{c}\text { Multiple } \\
\text { R-square }\end{array}$ & $\begin{array}{c}\text { R-square } \\
\text { change }\end{array}$ & $\begin{array}{c}\mathrm{F} \text { - to } \\
\text { entr/rem }\end{array}$ & p-level & $\begin{array}{c}\text { Variables } \\
\text { included }\end{array}$ \\
\hline $\begin{array}{l}\text { Morpho- } \\
\text { logy }\end{array}$ & 1 & 0.463 & 0.215 & 0.215 & 30.609 & $0.000^{* * *}$ & 1 \\
\hline $\begin{array}{l}\text { Study- } \\
\text { year }\end{array}$ & 2 & 0.511 & 0.262 & 0.047 & 7.052 & $0.009 * *$ & 2 \\
\hline VIQ & 3 & 0.547 & 0.300 & 0.038 & 5.986 & $0.016^{*}$ & 3 \\
\hline RSES & 4 & 0.564 & 0.318 & 0.018 & 2.875 & 0.093 & 4 \\
\hline $\begin{array}{l}\text { Living } \\
\text { abroad }\end{array}$ & 5 & 0.578 & 0.334 & 0.016 & 2.612 & 0.109 & 5 \\
\hline $\mathrm{a}-\mathrm{b}$ & 6 & 0.585 & 0.343 & 0.009 & 1.438 & 0.233 & 6 \\
\hline AACS & 7 & 0.588 & 0.345 & 0.003 & 0.425 & 0.516 & 7 \\
\hline PNS & 8 & 0.589 & 0.347 & 0.002 & 0.247 & 0.620 & 8 \\
\hline $\mathrm{a}+\mathrm{b}$ & 9 & 0.590 & 0.348 & 0.001 & 0.179 & 0.673 & 9 \\
\hline
\end{tabular}


Table 4. Elimination of the impact of the other variables on the dependent variable Syntax

\begin{tabular}{|c|c|c|c|c|}
\hline & Toleran. & R-square & Partial Cor. & Semipart Cor \\
\hline Morphology & 0.883 & 0.118 & $-0.464 * * *$ & $-0.423 * * *$ \\
\hline Study-year & 0.946 & 0.055 & $-0.274 * *$ & $-0.230 * *$ \\
\hline VIQ & 0.847 & 0.153 & $0.239^{*}$ & $0.198^{*}$ \\
\hline RSES & 0.667 & 0.333 & -0.080 & -0.065 \\
\hline Living abroad & 0.919 & 0.081 & -0.180 & -0.148 \\
\hline$a-b$ & 0.925 & 0.075 & -0.116 & -0.094 \\
\hline AACS & 0.638 & 0.363 & -0.046 & -0.038 \\
\hline PNS & 0.892 & 0.108 & 0.053 & 0.043 \\
\hline$a+b$ & 0.946 & 0.054 & 0.041 & 0.034 \\
\hline
\end{tabular}

mination index (R-square) went up by 0.009 , i.e., this model explains $34 \%$ variability of the variable syntactic ability (Syntax). In the seventh step, the variable $A A C S$ was entered, in the eight step $P N S$, in the ninth step $a+b$, and in all three steps the determination index (R-square) went up approximately by 0.002 .

After the seventh step we achieved a model with seven variables, which explains $34 \%$ variability of the dependent variable Syntax.

We found out that the variables Morphology (Score in Morphology), Study-year, and VIQ caused statistically significant contribution to the variability explanation of the dependent variable syntactic ability (Syntax).

The stepwise analysis showed that Morphology or grammatical skills (correct use of grammar), study-year, and verbal intelligence have statistically significant impact on syntactic abilities in the English language. The impact on syntactic abilities was shown in self-esteem, living abroad and in real estima- tion of the students, which has not been proven statistically.

Partial and semi-partial correlations (Table 4) show that the highest dependence, excluding the impact of other independent variables, is between the variable Syntactic ability and the variables Morphology Score, Study-year and Verbal Intelligence. There is an average indirect proportional dependence between Syntactic Ability and Morphology. Partial correlation is statistically significant. Similarly, there is a low indirect proportional dependence between the variable Syntactic Ability (Syntax) and Studyyear; and vice versa there is a low direct proportional dependence between the variable Syntactic Ability (Syntax) and verbal intelligence. Partial correlations are statistically significant. There is a low indirect proportional dependence between the variable Syntactic ability and the variables Living abroad, $a-b$, with the exclusion of the impact of other independent variables, but the coefficients are statistically insignificant. 


\section{DISCUSSIONAND CONCLUSION}

Our research focused on determining the impact of individual variables on syntactic abilities of students of English because the area of impacts on syntactic abilities has not been profoundly explored yet.

The hypothesis saying that "There is a positive relation between syntactic ability and linguistic variables (Morphology Score and Verbal Intelligence)" has been proven only in case of the variable Verbal intelligence. On the other hand, a statistically significant negative correlation has been proven with the variable Morphology Score, which means that the higher the syntactic ability level, the lower (better) the Morphology score or better performance in creating correct grammatical structures and vice versa.

It can be assumed that there is a connection between syntax and morphology of a language. Morphology (focuses on the internal structure of words) is the basic pillar for syntax (the structure of sentences), in other words, it focuses on the structure of words and word formation patterns in a language. We consider morphology to be the primary technology for a higher degree of language abilities and skills such as syntax. Syntax or syntactic reasoning requires a feel for the language, verbal creativity and understanding of principles and rules of linking words into phrases, clauses and sentences.

Remarkable is the statistically significant positive relation between syntactic ability in foreign language and verbal intelligence. It points to the existence of a relation between general linguistic ability in the mother tongue and specific linguistic ability in a foreign language, i.e., an individual with linguistic pre- dispositions has a higher probability of having an increased syntactic ability in a foreign language.

The second hypothesis saying that "There is a positive relation between syntactic ability and cognitive-individual variables ( $\mathrm{Abil}$ ity to Achieve Cognitive Structure, Cognitive Style 'Category Width' and Self-esteem) and a negative relation between syntactic ability and Personal Need for Structure." has not been proven. It is a remarkable finding, since we assumed that a student's cognitive structuration or individual ways of processing sentence constructions depend on his/her syntactic ability in a foreign language. Each individual perceives, processes, produces and interprets sentence constructions in a foreign language in a specific way. For this reason, it is complicated to examine the influences of personality on the acquisition of syntactic ability in a foreign language.

The third hypothesis saying that "There is a positive relation between syntactic ability and demographic variables (Grade, Study-year and Living Abroad)" has not been proven either. Actually, what was proven is a statistically significant negative relation between syntactic ability and the variable Study-year. The longer the students study English the lower their syntactic ability in English. This finding opens up new possibilities for research in terms of interference of syntactic structures of mother tongue (effort to reset parameters in foreign language, not to acquire them) and the age factor (starting with foreign language acquisition in early childhood and older school age, taking into account the implicit and explicit theories of learning).

The fourth hypothesis saying that " $\mathrm{Cog}$ nitive-individual, linguistic and demographic 
variables have a statistically significant effect on syntactic ability (using forward stepwise regression)" has been proven for linguistic variables Morphology Score and Verbal Intelligence, and for the demographic variable Study-year.

On the basis of the coefficients of tolerance, the examined independent variables are not redundant, i.e., all examined independent variables could be included into creating regression models explaining the dependent variable syntactic ability (test score in syntactic ability). A statistically significant contribution to explaining the variability of syntactic ability was manifested by the variables Morphology Score, Study-year and Verbal Intelligence, which explain about $30 \%$ of the variability of syntactic ability. A remarkable finding is also the slight indirect proportional dependence between syntactic ability and self-esteem of students (the fourth variable influencing the students' sentence structure). Although it has not been statistically proven, we see another opportunity for research in this area. We agree with Liu (2012) who found a high dependence of self-esteem on students' performance in a foreign - English language. He sees self-esteem as a strong predictor for students' performance in English.

The fifth hypothesis saying that "There is a positive relation between linguistic variables and cognitive-individual variables (Ability to Achieve Cognitive Structure, Cognitive Style 'Category Width' and Selfesteem) and a negative relation between syntactic ability and Personal Need for Structure" has been proven in the case of the linguistic variable Verbal Intelligence and the cognitive-individual variable Personal Need for Structure. Verbal Intelligence negatively correlates with Personal Need for
Structure. The lower the Personal Need for Structure, the higher the Verbal Intelligence or the higher the tolerance for uncertainty of a situation. Students take more risk, behave intuitively in creating sentence constructions, rely on their linguistic intuition and on their ability to create word and sentence constructions; they do not copy, they do not always look for the rule for word structures and patterns for creating sentences or fixed sentence constructions. We agree with Chapelle, Robertson (1986) and Brown (2000) who claim that the tolerance for ambiguity is closely connected to a successful foreign language acquisition and is essential for it.

Other remarkable statistically significant relations are a positive correlation between the Ability to Achieve Cognitive Structure and Self-Esteem, and a negative correlation between the Ability to Achieve Cognitive Structure and the Personal Need for Structure. The higher the thinking flexibility of students in a foreign language, the lower their Personal Need for Structure and the higher their Self-Esteem. Interesting is a positive dependence between the Ability to Achieve Cognitive Structure and the Study-year. The higher Study-year students are in, the higher their Ability to Achieve Cognitive Structure in a foreign language. Krashen (1982) claims that adult individuals can better regulate the quality and quantity of the input.

The results of our research open up new possibilities for further research - identifying variables explaining the remaining $70 \%$ of variability of the syntactic ability of students studying foreign languages at Slovak universities.

Received November 21, 2011 


\section{REFERENCES}

BAR-TAL, Y., 1994, The effect of need and ability to achieve cognitive structure on mundane decision making. European Journal of Personality, 8, 45-58.

BAR-TAL, Y., SPITZER, A., 1999, The need and ability to achieve cognitive structuring: Individual differences that moderate the effect of stress on information processing. Journal of Personality and Social Psychology, 77, 1, 3351.

BAR-TAL, Y., GUINOTE, A., 2002, Who exhibits more stereotypical thinking? The effect of need and ability to achieve cognitive structure on stereotyping. European Journal of Personality, 16, 313-331. doi: 10.1002/per.453.

BLATNÝ, M., OSECKÁ, L., 1994, Rosenbergova škála sebehodnocení: Struktura globálního vztahu k sobě. Československá Psychologie, 38, 6, 481-488.

BROWN, H.D., 2000, Principles of language learning and teaching (4th ed.). New York: Longman.

BROWN, R.A., 2008, Censure avoidance and selfesteem. Journal of Social Psychology, 148, 653666.

CAMERON, L., 2001, Teaching languages to young learners. Cambridge: Cambridge University Press.

CARROLL, J.B., 1997, Psychometrics, intelligence, and public perception. Intelligence: $A$ Multidisciplinary Journal, 24, 1, 25-52.

CHAPELLE, C., ROBERTS, CH., 1986, Field independence and ambiguity tolerance as predictors of proficiency in English as a second language. Language Laerning 36, 1, 27-46.

CHOMSKY, N., 1972, Language and mind. New York: Harcourt Brace Jovanovich.

COOPER, C., 2002, Individual differences. London: Arnold.

COOPERSMITH, S., 1981, Self-esteem inventories. Palo Alto, CA: Consulting Psychologists Press, Inc.

DALGAS-PELISH, P., 2006, Effects of a selfesteem intervention program on school-age children. Pediatric Nursing, 32, 341-348.

DOLNÍK, J., 2007, Jazyková inteligencia ako predpoklad jazykovej tvorivosti. In: O. Orgoňová (Eds.), Jazyk a komunikácia v súvislostiach. Bratislava: Univerzita Komenského.
DÖRNEY, Z., SKEHAN, P., 2003, Individual differences in second language learning. In: C. Doughty, M. Long (Eds.), Handbook of Second Language Acquisition. Oxford: Blackwell.

EHRMAN, M.E., OXFORD, R.L., 1990, Adult language learning styles and strategies in an intensive training setting. The Modern Language Journal, 74, 311-327.

EHRMAN, M.E., OXFORD, R.L., 1995, Cognition plus: Correlates of language learning success. The Modern Language Journal, 79, 67-89.

EYSENCK, M.W., KEANE, M.T., 2008, Kognitivni psychologie. Praha: Academia.

FICKOVÁ, E., 2000, Negatívna afektivita/ emocionalita a sebahodnotenie adolescentov. In: Z. Ruiselová (Ed.), Adjustačné problémy, charakteristiky zvládania a osobnost' adolescentov (pp. 55-64). Bratislava, Ústav experimentálnej psychológie SAV.

GARDNER, H., 1999, Dimenze myšleni: Teorie rozmanitých inteligencí. Praha: Portál.

GURŇÁKOVÁ, J., 2000, Negative self-esteem and preferred coping strategies in Slovak university students. Studia Psychologica, 42, 1-2, 75-86.

HALAMA, P., TOMKOVÁ, E., 2005, Subtesty inteligenčného testu IST-70 ako prediktory školského výkonu v rôznych typoch stredných škôl. In: I. Sarmány-Schuller, M. Bratská (Eds.), Zbornik Psychológia pre život alebo ako je potrebná metanoia - 23. Psychologické dni. Bratislava: SPS pri SAV, Dunajská Streda: PELIKÁN, s.r.o.

HORWITZ, E.K., HORWITZ, M.B., COPE, J., 1986, Foreign language classroom anxiety. The Modern Language Journal, 70, 2, 125-132.

JOHN, M.J., CALlAN, S., PROCTOR, S., HOLSTE, S.T., 2000, Tactical decision-making under uncertainty: Experiments $I$ and II. San Diego, CA: Space and Naval Warfare Systems Center.

JURČOVÁ, M., SARMÁNY-SCHULLER, I., 1993, Kognitívny štýl „šírka kategorizácie“. Československá Psychologie, 37, 1, 1-13.

KRASHEN, S., 1982, Principles and practice in second language acquisition. Oxford: Pergamon Press.

LENNEBERG, E.H., 1967, Biological Foundations of Language. [online], [cit.2013-20-05] Available from: http://books.google.com/books/ about/Biological_foundations_of_language. html?id=7UZiAAAAMAAJ

LIU, M., 2012, Predicting effects of personality traits, self-esteem, language class risk-taking and sociability on Chinese university EFL learners' Per- 
formance in English. Journal of Second Language Teaching and Research, 1, 1, 30

NEUBERG, S.L., NEWSOM, J.T., 1993, Personal need for structure: Individual differences in the desire for simple structure, Journal of Personality and Social Psychology, 65, 113-131.

NEUBERG, S.L., WEST, S.G., JUDICE, T.N., THOMPSON, M.M., 1997, On dimensionality, discriminant validity, and the role of psychometric analyses in personality theory and measurement: Reply to Kruglanski et al.'s (1997) defense of the Need for Closure Scale. Journal of Personality and Social Psychology, 73, 5, 1017-1029.

PETTIGREW, T., 1958, The measurement of category width as a cognitive variable. Journal of Personality, 26, 532-544.

PIAGET, J., 1970, Genetic epistemology. New York: W.W. Norton and Company.

PINKER, S., 2009, Jazykový instinkt: Jak mysl vytvář́i jazyk. Praha: Dybbuk

REPKA, R., GAVORA, P., 1987, Didaktika angličtiny. Bratislava: SPN.

RIEMER, C., 1997, Individuelle Unterschiede im Fremdsprachenerwerb. Hohengehren: Schneider.

ROSENBERG, M., 1965, Society and the adolescent self-image. Princeton: Princeton University Press.

SARMÁNY-SCHULLER, I., 1997, Integrálne výsledky výskumov kognitívnych štýlov a praktická inteligencia. In: I. Sarmány-Schuller, I. Ruisel (Eds.), Zborník Praktická inteligencia IV., Bratislava: ÚEPs SAV.

SARMÁNY-SCHULLER, I., 1999, Neistota istota / prípad kauzálnej neistoty. In: I. SarmánySchuller, M. Bratská, E. Naništová (Eds.), Reflexie súčasnej psychológie na Slovensku, Zborník príspevkov IX. zjazdu slovenských psychológov, Bratislava: STIMUL.

SITU, Q-M., LI, J-B., 2007, Relationship between self-esteem and interactive anxiety. China Journal of Health Psychology, 15, 1005-1007.

SKEHAN, P., 1998, A cognitive approach to language learning. Oxford: University Press.

STERNBERG, R.J., 2009, Kognitivní psychologie. Praha: Portál.

STRANOVSKÁ, E., 2011, Psycholingvistika: Determinanty osvojovania si a učenia sa cudzieho jazyka a kultúry. Brno: MSD.

STRANOVSKÁ, E., FRÁTEROVÁ, Z., MUNKOVÁ, D., MÜGLOVÁ, D., 2011, Politeness factors in requests formulated in the category width cognitive style. Studia Psychologica, 2, 54, 111124.

STRINGER, R.W., HEATH, N., 2008, Academic self-perception and its relationship to academic performance. Canadian Journal of Education, 31, 327-345.

THOMPSON, M.M., NACCARATO, M.E., PARKER, K.E., 1992, Measuring cognitive needs: The development and validation of the Personal Need for Structure (PNS) and Personal Fear of Invalidity (PFI) measures. Journal of Personality and Social Psychology, 65, 1, 113-131.

UŽÁKOVÁ, M., DANO, D., MUNKOVÁ, D., 2010, English Syntax. ASPA: Nitra.

VÁGNEROVÁ, M., 2001, Testy speciálních schopností, znalostí a dovedností. In: M. Svoboda, D. Krejčířová, M. Vágnerová (Eds.), Psychodiagnostika détí a dospivajicich. Praha: Portál.

WATKINS, D., 2000, Learning and teaching: A cross-cultural perspective. School leadership \& Management, 20, 161-173. 


\title{
KOGNITÍVNO-OSOBNOSTNÉ, JAZYKOVÉ, DEMOGRAFICKÉ PREMENNÉ A SYNTAKTICKÁ ZRUČNOSŤ V CUDZOM JAZYKU
}

\author{
E. S t ranovská, D. Munková, M. Munk, I. S a r mán y S c hu 11 e r
}

Súhrn: Výskum bol zameraný na zistenie miery vplyvu kognitívno-osobnostných (potreba štruktúry, schopnost' vytvorenia kognitívnej štruktúry, sebahodnotenie, kognitívny štýl „širka kategorizácie“), jazykových (verbálna inteligencia, známka z morfológie) a demografických premenných (dížka štúdia, ročník, pobyt $v$ zahraniči) na syntaktickú zručnost' študentov anglického jazyka a kultúry na UKF v Nitre. Zistit' vzt’ah syntaktickej zručnosti so skúmanými premennými. Použili sme výskumné metódy: Škála PNS (Thompson a kol., 1992), AACS (Bar-Tal, 1994), RSES (Rosenberg, 1965), $C-W$ (Pettigrew, 1958), I-S-T (Amthauer, 1953, v Halama, Tomková, 2005), Test syntaktických zručností (Užáková a kol., 2010). Výsledky ukázali negatívnu koreláciu syntaktickej zručnosti a známky z morfológie, dížky štúdia, známky z morfológie a ročníku. Pozitívnu koreláciu syntaktickej zručnosti s verbálnou inteligenciou. Negatívnu koreláciu medzi jazykovou premennou (verbálna inteligencia) a kognitívno-osobnostnou (potreba štruktúry). Sledované premenné vysvetlujú $34 \%$ variability syntaktickej zručnosti v cudzom jazyku. 